\title{
The Microbiology of Surgical Infections
}

\author{
Mihaela Leșe \\ General Surgery Department \\ Baia Mare Emergency County Hospital \\ Micu-Chis R D ${ }^{2}$ \\ General Surgery Department \\ Cluj-Napoca Municipal Clinical Hospital
}

\begin{abstract}
Objective. The purpose of the study is the inventory of isolated pathogens from the patients treated in the General Surgery Department of the Baia Mare Emergency County Hospital, the associated treatment, the postoperative mortality and the related costs.

Materials and methods. All positive cultures from samples collected in 2017 from patients hospitalized in general surgery department (surgical wound, peritoneal fluid, sputum, urine, stool, hemoculture, tegument) were selected. From the patient files, the type of surgical procedures performed, duration of hospitalization, costs related to their hospitalization, antibiotic therapy and postoperative progression was retained.

Results. A number of 411 patients were diagnosticated with infections (11.47\% of all patients hospitalized in 2017) and 686 bacteriaidentified. There were 149 infections with E. coli (36.3\%), 87 with Coagulase-negative staphylococcus (21.2\%), 78 with Enterococcus (19\%), 67 with Streptococcus viridans (16.3\%) and 58 with methicillin-sensitive Staphylococcus (14.1\%). Most deaths were associated with Escherichia coli infection - 22 patients (56.4\% of the patients infected with this bacterium, $p=0.01)$, and out of all the germs, Acinetobacter baumannii was the only one found more frequently in healthcare-associated infections compared to communityacquired infections (17 vs. 6).The average length of hospital stay in patients with infections was 10.9 days compared to the average length of stay of all the patients in 2017 which was 5.6 days. Mortality was $9.7 \%$ in patients with infections, compared with a general mortality of $4.8 \%$ in 2017.Certain risk factors, such as anemia, prolong the length of hospitalization and increase the risk of death .

Conclusions. The most common infections treated in the General Surgery Department were those communityacquired. The most common deaths were reported in patients infected with E. coli, Enterococcus, Candida and Acinetobacter. Stricter isolation of patients infected with Acinetobacter baumannii is required. The association of anemia in the patients hospitalized with infections significantly increases the risk of death and prolongs the duration of hospitalization.
\end{abstract}

Keywords: infection, E. coli, Enterococcus, Candida, Acinetobacter, anemia, average length of stay, cost, postoperative mortality

\section{Introduction}

The definition of surgical infection is totally different from that of operative wound infection, nosocomial infection or postoperative peritoneal abscess, entities which it is true that, among other things, are included in it. Surgical infection is the result of the action ofgerms whose effect must be corrected by surgery, by percutaneous minimally invasive techniques, and / or medical treatment (1).Broadly speaking, these are all infections that require surgical treatment or are related to it. Germs produce infection by crossing the body's natural barriers - the skin, gastrointestinal mucosa, respiratory epithelium or genitourinary system, through translocation, trauma, surgical incisions, ischemia, tumor invasion or obstruction of the digestive, biliary or urinary tract (2). Bacteria on the skin may become pathogenic by contaminating the surgical wound, and hence may result in a pneumonia (eg Staphylococcus aureus), or vice versa, a pathogenic bacteria in the respiratory tract may become the most virulent bacteria in a wound, as it happens with Acinetobacter strains.In addition to pathogenicity, bacterial motility adds importance to any germ involved in a surgical infection, that in this way may worsen, may cause new outbreaks of infection, and it may cause the patient to die. 
Identification of germs at the site of surgical infection (wound, sputum, stool, urine, etc.), regardless of the location and form of expression, does not indicate, unfortunately, their pathogenicity, so the antibiotic administered can address the non-pathogenic germ and can select other germs who will later become pathogens (3). The infection is a dynamic process in which pathogenic flora often changes, microbial associations with synergism between germs and extremely varied virulence factors occur. On the other hand, each hospital has its own microbial ecosystem that affects hospitalized patients and is also influenced by their microbiota, in time,persistent germs gaining resistance to commonly used antibiotics through multiple genetic mutations (4).

The aim of our study is to identify the most common bacteria involved in surgical infections, how they affected the healing process of patients and what were the associated costs in a general surgery service.

\section{Materials and methods}

The study is retrospective and data was collected from the year 2017 (1 January, 31 December) from the General Surgery Department (GSD) of the Baia Mare Emergency County Hospital (BMECH), where 411 patients with surgical infections were identified, out of a total of 3,582 patients admitted. Patients admitted to the daycare compartment were excluded. The data were obtained from the HIPOCRATE computer system and from the National School of Public Health, Healthcare Management and Improvement, by selecting the conventional microbiology laboratory results which identified the presence of germs in samples taken from the surgical wounds, urine, sputum, stool, skin or through hemocultures. These samples were collected only from patients with clinical signs of infection. From their e-files were recorded: age, gender, DRG disease code (ICD 10), blood glucose level, leukocytes and hematocrit at admission, type of wound - clean, clean / contaminated , contaminated or dirty -, the type of isolated bacteria, the antibiotics administered, the postoperative evolution towards healing/amelioration or death, the antibiotics administered, the length of hospitalization and the cost of hospital day in each of these patients. The data obtained were statistically processed with the MedCalc Statistical Software version 18.2.1 (Ostend, Belgium) and the statistical significance was considered for $p<0.05$. There was no need for informed consent from patients. The study was approved by the hospital ethics committee.

\section{Results}

During the year 2017 in GSD of BMECH 3582 patients were hospitalized, of which 411 had infections and 686 bacterial strains were isolated: 538 strains of these were identified in the first 48 hours of enrollment, at 352 (85.64\%) patients (community-acquired infections). There were 88 patients with monomicrobial infections (21.41\%), and at the remaining $323(78.59 \%)$ there were identified two or more types of germs. Most commonly identified (treated) infections were with E. coli (149- 36.3\%), Coagulase-negative Staphylococci (87-21.2\%), Enterococcus (78-19\%) and Methicillin-sensitive Staphylococcus aureus (58-14.1\%), as can be seen in Table 1.

\begin{tabular}{|l|c|c|c|c|c|c|c|c|c|c|c|c|c|}
\hline \multicolumn{2}{|c|}{ Table 1. Frequency of isolated germs in patients in 2017 } \\
\hline $\begin{array}{l}\text { Bacte } \\
\text { rium }\end{array}$ & $\begin{array}{c}\text { Staph } \\
\text { aureu } \\
\text { S } \\
\text { MSS } \\
\text { A }\end{array}$ & $\begin{array}{c}\text { Staph } \\
\text { aureu } \\
\text { s } \\
\text { MRS } \\
\text { A }\end{array}$ & $\begin{array}{c}\text { Enter } \\
\text { ococc } \\
\text { us }\end{array}$ & $\begin{array}{c}\text { Kle } \\
\text { bsiel } \\
\text { la }\end{array}$ & $\begin{array}{c}\text { Entero } \\
\text { bacter }\end{array}$ & $\begin{array}{c}\text { Pseudo } \\
\text { monas }\end{array}$ & $\begin{array}{c}\text { Can } \\
\text { dida }\end{array}$ & $\begin{array}{c}\text { Acineto } \\
\text { bacter }\end{array}$ & $\begin{array}{c}\text { Prot } \\
\text { eus }\end{array}$ & $\begin{array}{c}\text { Coagul } \\
\text { ase- } \\
\text { negativ } \\
\text { e } \\
\text { Staph. }\end{array}$ & $\begin{array}{c}\text { Strep } \\
\text { virida } \\
\text { ns }\end{array}$ & $\begin{array}{c}\text { E. } \\
\text { coli }\end{array}$ & $\begin{array}{c}\text { Beta } \\
\text { hemoly } \\
\text { tic gr C } \\
\text { strep. }\end{array}$ \\
\hline $\begin{array}{l}\text { No. of } \\
\text { patie } \\
\text { nts }\end{array}$ & 58 & 41 & 78 & 39 & 16 & 22 & 13 & 23 & 16 & 87 & 67 & 149 & 6 \\
\hline $\begin{array}{l}\text { Freq } \\
\text { uency } \\
(\%)\end{array}$ & 14,1 & 10 & 19 & 9,5 & 3,9 & 5,4 & 3,2 & 5,6 & 3,9 & 21,2 & 16,3 & 36,3 & 1,5 \\
\hline
\end{tabular}

Clostridium difficile infection was diagnosed in one patient $(0.24 \%)$ on the first day of admission to the department.Regarding the germ classes (Table 2), we found that the anaerobic germs are almost equal to the aerobic ones, with the gram-positive bacteria predominating (compared to the gram-negative ones), identified in a number of 267 patients $(38.92 \%)$. 


\begin{tabular}{|l|c|}
\hline Table 2. Classification of germs identified in patients \\
\hline Type of germ & No of Patients / Percentage \\
\hline Gram-positive & $267(38,92 \%)$ \\
\hline Gram-negative & $45(6,55 \%)$ \\
\hline Anaerobic & $330(48,1 \%)$ \\
\hline Candida spp & $13(1,89 \%)$ \\
\hline Others & $31(4,51 \%)$ \\
\hline
\end{tabular}

Comparing the association of the bacterial classes with evolution towards death, we found statistical significance for gram-negative germs $(\mathrm{p}=0.002)$, as well as their association with the other classes (Table 3): gram-negative + gram-positive $(\mathrm{p}=0.032)$ andgram-negative+ anaerobic $(\mathrm{p}=0.009)$.

\begin{tabular}{|l|c|c|c|}
\hline \multicolumn{4}{|c|}{ Table 3. Association of germ classes with evolution towards death } \\
\hline $\begin{array}{l}\text { Association of } \\
\text { germs }\end{array}$ & $\begin{array}{c}\text { No of } \\
\text { patients }\end{array}$ & Death & P value \\
\hline Gram-positive & 170 & 19 & 0,418 \\
\hline Gram-negative & 370 & 29 & $\mathbf{0 , 0 0 2}$ \\
\hline Anaerobic & 160 & 9 & 0,050 \\
\hline $\begin{array}{l}\text { Gram-positive + } \\
\text { gram-negative }\end{array}$ & 403 & 36 & $\mathbf{0 , 0 3 2}$ \\
\hline $\begin{array}{l}\text { Gram-positive + } \\
\text { anaerobic }\end{array}$ & 319 & 26 & 0,085 \\
\hline $\begin{array}{l}\text { Gram-negative + } \\
\text { anaerobic }\end{array}$ & 377 & 31 & $\mathbf{0 , 0 0 9}$ \\
\hline
\end{tabular}

We studied the associations of different germs with the age and gender of the patients and foundCoagulasenegative staphylococcal infections in 19 patients out of 104 patients with disease in the 7th-age decade $(p=0.022)$ and no statistically significant association with the gender of the patients. Patients who have had Streptococcus viridans and E. coli infections had associated, from the internment, leukocytosis $\left(>11,000 / \mathrm{mm}^{3}\right)$ in a statistically significantly higher number $(\mathrm{p}=0.012$ and $\mathrm{p}=0.001)$ compared to the rest of the germs. In cases with Enterococcus, Klebsiella and Pseudomonas infection, anemia was associated (hematocrit below 35\%) statistically significantly more frequent than in the rest of the germs: $p=0.010, p=0.018$ and $p=0.040$.

\begin{tabular}{|c|c|c|c|c|c|c|c|}
\hline Germ & $\begin{array}{c}\text { Enterococc } \\
\text { us }\end{array}$ & Klebsiella & Candida & $\begin{array}{c}\text { Acinetobacte } \\
\mathrm{r}\end{array}$ & $\begin{array}{l}\text { Morganella } \\
\text { spp }\end{array}$ & $\begin{array}{l}\text { Streptococcus } \\
\text { viridans }\end{array}$ & E. coli \\
\hline $\begin{array}{l}\text { Disease, } \\
\text { DRG } \\
\text { group }\end{array}$ & $\begin{array}{c}\text { K6, } \\
\text { peritonitis }\end{array}$ & $\begin{array}{l}\text { K8, biliary } \\
\text { infections }\end{array}$ & $\begin{array}{c}\text { K3, acute } \\
\text { appendicitis }\end{array}$ & $\begin{array}{l}\text { K8, biliary } \\
\text { infections }\end{array}$ & $\begin{array}{l}\text { K8, biliary } \\
\text { infections }\end{array}$ & $\begin{array}{c}\mathrm{K} 3 \text {, acute } \\
\text { appendicitis }\end{array}$ & $\begin{array}{c}\text { K6, } \\
\text { peritonitis }\end{array}$ \\
\hline $\begin{array}{l}\text { No of } \\
\text { patients } \\
\text { /percent }\end{array}$ & $\begin{array}{c}12 \\
(15,4 \%)\end{array}$ & $\begin{array}{c}12 \\
(30,8 \%)\end{array}$ & $\begin{array}{c}3 \\
(23,1 \%)\end{array}$ & $\begin{array}{c}5 \\
(21,7 \%)\end{array}$ & $\begin{array}{c}7 \\
(41,2 \%)\end{array}$ & $\begin{array}{c}17 \\
(25,4 \%)\end{array}$ & $\begin{array}{c}30 \\
(20,1 \%)\end{array}$ \\
\hline P value & 0,001 & 0,001 & 0,018 & 0,016 & 0.001 & 0,001 & 0,001 \\
\hline
\end{tabular}

The tropism of germs for different systems and organs was statistically validated in several cases (Table 4).We have found that peritonitis was mainly the site of E. coli and Enterococcus infections; germs such as Acinetobacter, Klebsiella and Morganella have been found most often in gallbladder infections, and in acute appendicitis the most common infections were with Streptococcus viridans and Candida. 
In terms of infections of various types of plague, we found that Coagulase-negative staphylococcus was statistically significantly more frequently found in dirty plaques: it was isolated from 38 wounds from a total of 183 wounds considered dirty $(20.8 \% \mathrm{p}=0.001)$.

The highest cost of hospital day was found for Enterococcus, Candida and Acinetobacter infections, the median difference of cost per day of hospitalization was 65.5 RON, 264 RON and 476.75 RON, respectively, compared to patients who did not have infections with these germs and the value of $\mathrm{p}$ was $<0.001$ in all three cases.

Treatment of surgical infections in BMECH was most frequently performed with Ceftazidime in 217 patients, Amoxicillin and Clavulanic Acid (Augmentin) - 148 patients, Metronidazole in 134 patients with infections, and Gentamicin in 100 cases (Table 5).

Table 5.Antibiotics given to patients with surgical infections

\begin{tabular}{|c|c|c|c|c|c|c|c|c|c|c|c|c|c|c|c|}
\hline $\begin{array}{l}\text { Anti } \\
\text { bioti } \\
\text { cs }\end{array}$ & $\begin{array}{c}\text { Cefta } \\
\text { zidim } \\
\text { e } 1 \mathrm{~g}\end{array}$ & $\begin{array}{c}\text { Aug } \\
\text { ment } \\
\text { in } \\
1,2 \mathrm{~g}\end{array}$ & $\begin{array}{c}\text { Metro } \\
\text { nidazo } \\
\text { le } \\
1500 \\
\mathrm{mg}\end{array}$ & $\begin{array}{c}\text { Gent } \\
\text { amic } \\
\text { in } \\
80 \mathrm{~m} \\
\mathrm{~g}\end{array}$ & $\begin{array}{c}\text { Erta } \\
\text { pene } \\
\mathrm{m} \\
1 \mathrm{~g}\end{array}$ & $\begin{array}{c}\mathrm{Su} \\
\text { lce } \\
\mathrm{f} \\
1 \mathrm{~g}\end{array}$ & $\begin{array}{c}\text { Fluco } \\
\text { nazol } \\
\text { e } 100 \\
\text { mg }\end{array}$ & $\begin{array}{c}\text { Ciprof } \\
\text { loxaci } \\
\text { n } 100 \\
\text { mg }\end{array}$ & $\begin{array}{c}\text { Levof } \\
\text { loxaci } \\
\text { n } 500 \\
\text { mg }\end{array}$ & $\begin{array}{c}\text { Ceftr } \\
\text { iaxon } \\
\mathrm{e} \\
1 \mathrm{~g}\end{array}$ & $\begin{array}{c}\text { Clind } \\
\text { amici } \\
\text { n } 600 \\
\text { mg }\end{array}$ & $\begin{array}{l}\text { Mero } \\
\text { pene } \\
\mathrm{m} 1 \mathrm{~g}\end{array}$ & $\begin{array}{c}\text { Vanc } \\
\text { omyc } \\
\text { in } \\
1 \mathrm{~g}\end{array}$ & \begin{tabular}{|c|} 
Teic \\
oplan \\
in \\
400 \\
$\mathrm{mg}$
\end{tabular} & \begin{tabular}{|c|} 
Lin \\
ezol \\
id \\
600 \\
$\mathrm{mg}$
\end{tabular} \\
\hline $\begin{array}{l}\text { No. } \\
\text { of } \\
\text { patie } \\
\text { nts }\end{array}$ & 217 & 148 & 134 & 100 & 39 & 38 & 33 & 23 & 22 & 22 & 17 & 15 & 9 & 6 & 6 \\
\hline $\begin{array}{l}\text { Freq } \\
\text { uenc } \\
y \\
(\%)\end{array}$ & 52,8 & 36 & 32,6 & 24,3 & 9,5 & $\begin{array}{l}9, \\
2\end{array}$ & 8 & 5,6 & 5,4 & 5,4 & 4,1 & 3,6 & 2,2 & 1,5 & 1,5 \\
\hline $\begin{array}{l}\text { Pric } \\
\text { e/UT } \\
\text { RO } \\
\text { N } \\
\text { (wit } \\
\text { h } \\
\text { VAT } \\
\text { ) }\end{array}$ & 6,7 & 5,1 & 3,6 & 9,5 & 183 & $\begin{array}{c}18 \\
, 5\end{array}$ & 30,5 & 3,3 & 37,7 & 13,3 & 5,5 & 57,2 & 48,3 & 118,1 & $\begin{array}{c}105 \\
2\end{array}$ \\
\hline
\end{tabular}

The treatment was empirically administered in the first 3 days, generally with broad spectrum antibiotics and lower cost (between 3 and $10 \mathrm{RON} /$ unit), and then according to the antibiogram, regardless of the price of the medicines (Table 5), the most expensive being Ertapenem (Invanz - 183 RON), glycopeptides (Targocid - 118,16 RON) and oxazolidinones (Linezolid - 105,26 RON). The most commonly used anti-infective combination was Ceftazidime with Metronidazole (Table 6) in 77 patients.

\begin{tabular}{|l|c|c|}
\hline Table 6. Associations of antibiotic drugs \\
\hline Frequent antibiotic association & No of Patients & Frequency \\
\hline Ceftazidime +Metronidazole & 77 & 18,7 \\
\hline Amoxiplus+Gentamicin & 55 & 13,3 \\
\hline Ceftazidime + Gentamicin & 43 & 10,4 \\
\hline Amoxiplus + Metronidazole & 35 & 8,4 \\
\hline
\end{tabular}

In the 411 patients with surgical infections hospitalized in 2017, 39 deaths were recorded. The death occurred most frequently in patients with E. coli (22 patients, 56.4\%, p =0.01), Enterococcus (14 patients, 35.9\%, p = 0.009), Acinetobacter (10 patients, 25.6\%, $\mathrm{p}=0.001$ ) and Candida (6 patients, $15.4 \%, \mathrm{p}=0.001$ ), as shown in Table 7. Of these, 22 had only germs identified in the first 48 hours, and 9 only infections occurred after the first two days, and from 8 patients were identified germs in both the first 48 hours and other germs emerged after this limit. In the case of the 6 deaths in Candida patients, the germ was isolated more than 48 hours after admission, 
being an infection associated with hospital care.The death rate is statistically significantly higher for infections diagnosed at admission ( $\mathrm{p}=0.001$, Pearson Chi-Square and Continuity Correction).

\begin{tabular}{|l|c|c|c|c|c|c|c|c|c|}
\hline Table 7. Association between germs and the death of patients & & & & & & & \\
\hline Germ & $\begin{array}{c}\text { Staph } \\
\text { aureus } \\
\text { MSSA }\end{array}$ & $\begin{array}{c}\text { Staph. } \\
\text { aureus } \\
\text { MRSA }\end{array}$ & Enterococcus & Klebsiella & Pseudomonas & Candida & Acinetobacter & $\begin{array}{c}\text { Streptococcus } \\
\text { viridans }\end{array}$ & $\begin{array}{c}\text { E. } \\
\text { coli }\end{array}$ \\
\hline $\begin{array}{l}\text { No. of } \\
\text { deceased } \\
\text { patients }\end{array}$ & 5 & 2 & 14 & 7 & 3 & 6 & 10 & 8 & 22 \\
\hline $\begin{array}{l}\text { Frequency } \\
\text { (\%) }\end{array}$ & 12,8 & 5,1 & 35,9 & 17,9 & 7,7 & 15,4 & 25,6 & 20,5 & 56,4 \\
\hline P value & 0,99 & 0,4 & $\mathbf{0 , 0 0 9}$ & 0,079 & 0.45 & $\mathbf{0 , 0 0 1}$ & $\mathbf{0 , 0 0 1}$ & 0,60 & $\mathbf{0 , 0 0 1}$ \\
\hline
\end{tabular}

Regarding the association between death (39 deaths in total) and the values of biological constants at admission, we found that surgical infections in patients with anemia (hematocrit $<35 \%$ ), evolved statistically significantly more frequently towards death -21 patients $(53.8 \%), \mathrm{p}=0.001$ (Table 8$)$.

\begin{tabular}{|c|c|c|c|c|}
\hline $\begin{array}{l}\text { Changing biological } \\
\text { parameters }\end{array}$ & No. of patients & $\begin{array}{c}\text { No. of } \\
\text { deceased } \\
\text { patients }\end{array}$ & $\begin{array}{c}\text { Frequency } \\
\%\end{array}$ & $\begin{array}{c}\mathrm{P} \\
\text { value }\end{array}$ \\
\hline Blood sugar $>110 \mathrm{mg} / \mathrm{dl}$ & 177 & 23 & 59 & 0,053 \\
\hline Hematocrit < 35\% & 117 & 21 & 53,8 & 0,001 \\
\hline Leukocytes $>11.000 / \mathrm{mm}^{3}$ & 199 & 18 & 46,2 & 0,87 \\
\hline
\end{tabular}

We have studied the treatment for infections commonly associated with death, andthe antibiotics that were administered according to the antibiogram obtained 3 days after inoculating the samples on the culture media. We found that statistically significantly more frequently Invanz was administered for Enterococcus $(p=0.001)$, Candida $(p=0.004)$, Acinetobacter $(p=0.045)$ and E. coli $(p=0.001)$ infections as shown in Table 9. In Candida infections, antifungal treatment was not statistically significant used more frequently $(p=0.07)$.

Table 9.Antibiotics administered more frequently in death-related infections, according to antibiogram:
p value
\begin{tabular}{|l|c|c|c|c|c|c|c|c|c|c|c|c|c|c|}
\hline $\begin{array}{l}\text { Anti } \\
\text { bioti } \\
\text { cs }\end{array}$ & $\begin{array}{c}\text { Ceftaz } \\
\text { idime }\end{array}$ & $\begin{array}{c}\text { Augm } \\
\text { entin }\end{array}$ & $\begin{array}{c}\text { Genta } \\
\text { micin }\end{array}$ & $\begin{array}{c}\text { Metro } \\
\text { nidazo } \\
\text { le }\end{array}$ & $\begin{array}{c}\text { Ceft } \\
\text { riax } \\
\text { one }\end{array}$ & $\begin{array}{c}\text { Levofl } \\
\text { oxaci }\end{array}$ & $\begin{array}{c}\text { Fluco } \\
\text { nazole }\end{array}$ & Invanz & Sulcef & $\begin{array}{c}\text { Merop } \\
\text { enem }\end{array}$ & $\begin{array}{c}\text { Vanco } \\
\text { mycin }\end{array}$ & $\begin{array}{c}\text { Tar } \\
\text { goci } \\
\text { d }\end{array}$ & $\begin{array}{c}\text { Line } \\
\text { zoli } \\
\text { d }\end{array}$ & $\begin{array}{c}\text { Clinda } \\
\text { mycin }\end{array}$ \\
\hline $\begin{array}{l}\text { Ente } \\
\text { roco } \\
\text { ccus }\end{array}$ & 0,93 & 0,14 & 0.18 & $\mathbf{0 . 0 3}$ & $\mathbf{0 . 0 4}$ & 0.39 & $\mathbf{0 . 0 1 5}$ & $\mathbf{0 . 0 0 1}$ & 0.90 & $\mathbf{0 . 0 1}$ & $\mathbf{0 . 0 0 2}$ & 0.31 & 0.08 & 0.54 \\
\hline $\begin{array}{l}\text { Can } \\
\text { dida }\end{array}$ & 0.71 & 0.77 & 0.77 & $\mathbf{0 . 0 3 4}$ & 1 & 0.51 & 0.07 & $\mathbf{0 . 0 0 4}$ & 0.02 & 0.38 & 0.25 & 1 & 0.17 & 1 \\
\hline $\begin{array}{l}\text { Acin } \\
\text { etob } \\
\text { acter }\end{array}$ & 0.31 & 0.21 & 0.21 & 0.067 & 0.35 & 0.35 & 0.08 & $\mathbf{0 . 0 0 3}$ & 1 & $\mathbf{0 . 0 4 5}$ & $\mathbf{0 . 0 1}$ & 0.29 & 0.29 & 0.62 \\
\hline $\begin{array}{l}\text { E. } \\
\text { Coli }\end{array}$ & 0.97 & 1 & $\mathbf{0 . 0 0 2}$ & $\mathbf{0 . 0 0 1}$ & 0.82 & 0.81 & 1 & $\mathbf{0 . 0 0 1}$ & 0.13 & 1 & 0.72 & 1 & 1 & 0.73 \\
\hline
\end{tabular}

We found a higher frequency of treatment with Metronidazole $(\mathrm{p}=0.034)$, Ertapenem $(\mathrm{p}=0.004)$ and Sulcef (0.02) in patients with mycosis due to their association with other germs in polymicrobial infections. 


\section{Discussion}

Surgical infections are a wide range of infections, located in organs and systems sometimes remote, which may or may not share the same pathogenic flora. When present at admission, they are focal infections requiring evacuation and / or drainage, but when appearing during hospitalization they represent the selection of the pathogenic flora of the commensal flora due to the low host immunity or healthcarerelatedinfections. From the 411 patients which were admitted with surgical infections in GSD of BMECH, more than $85 \%$ hadfocal infections at admissionfor which they were operated, and in the first 48 hours more than $78 \%$ of the germs were identified, a specificationwe have not encountered so far in the literature; there are only studies that address wound infections, other postoperative abscesses and peritonitis, and others infections related to medical care.

The prevalence of polymicrobial infections found in our study - 78.59\% - is much more pronounced compared to the results of studies of intra-abdominal infections - 67\% (6) - and those found in diabetic patients - 58.7\% (7) - , the only ones we found in the literature, which is the consequence of design differences between studies.

Commensal germs were most commonly involved in focal surgery infections in BMECH. E.coli and Enterococcus became pathogens by bacterial translocation in lumen obstructions (e.g. acute appendicitis) or organ ischemia (acute cholecystitis) or by direct invasion of peritoneum in organ perforations $(8,9)$, and Coagulasenegative Staphylococcus and Methicillin-sensitive Staphylococcus aureus by penetration of the skin or mucosa barrier into skin infections or postoperative abscesses $(10,11)$.

The only infection with Clostridium difficile was detected in the GSD within the first 24 hours after the patient's hospitalization (community-acquired infection), as opposed to other studies where it reached up to $2.6 \%$ of the patients operated (12).Another 4 patients had this infection when they were transferred to our department. We managed to drastically limit pseudomembranous colitis by introducing a simple hygiene rule for patients: "Do not touch your mouth, nose or eyes unless you have washed your hands." This rule was even more severe after surgery, when it was forbidden to wet the lips of patients with handkerchiefs or wet napkins.

Important percentages (48.1\%) of the germs were anaerobes (predominantly Bacteroides and Peptostreptococcus) that originated from the patient's own flora.Anaerobic infections are favored by decreased tissue perfusion and, of course, tissue necrosis, as is the case in trauma, associated vascular disease, cancers, surgery, or edema (13). In our patients, the mortality associated with anaerobic infections was higher, at the limit of statistical significance (p $=0.05)$, their severity being due to microbial associations with synergistic effect and resistance to the most commonly used anti-anaerobic: Metronidazole, Clindamycin and Ampicillin / Sulbactam (14).

Gram-negative germs have a growing incidence in surgical services and are gradually gaining resistance to the most commonly used antibiotics (15). In our study, although the frequency with which they were isolated was reduced $(6.55 \%)$, they were associated with statistically significant mortality $(\mathrm{p}=0.002)$, alone or when found in combination with anaerobic germs $(\mathrm{p}=0.009)$.Increased mortality in these infections was attributed to inappropriate empirical antibiotic treatment, association of comorbidities (cancer, immunosuppressant, organ failure, etc.) and multiple hospitalizations $(16,17)$.

The presence of high leukocytes at admission was not associated with statistically significant increased mortality on the studied group. This result is in line with another study we published: only the presence of at least two criteria from systemic inflammatory syndrome is associated with statistically significant mortality (18).However, we found that leukocytosisis statistically significantly more frequently in patients with Viridans Streptococci and E. coli, an association that has not been previously reported in the literature, which can be explained by a more aggressive stimulation of the bone marrow in the case these germs.

Anemia that occurs during acute infections is mainly due to hemolysis, by direct invasion of the erythrocytes by bacteria, toxins that cause hemolysis, or antibodies and immune complexes produced by the germs (19). In our study, of all the germs, anemia was statistically significant associated with infections with Enterococcus, Klebsiella and Pseudomonas. We haven't found in the literature the association between Enterococcus and anemia, but there are studies that highlight the occurrence of anemia in endocarditis with Enterococcus. The authors explain the occurrence of anemia by hemolysis produced by friction forces at the site of infected valves $(20,21)$, but there might be associated hemolysis produced by these bacteria, amechanism insufficiently investigated. Klebsiella infection was also found associated with anemia $(22,23)$, as well as that with Pseudomonas (24), but was not confirmed in the literature on larger groups of patients. 
Although preoperative anemia is a well-known risk factor for postoperative mortality, this association has not been investigated in cases of surgical infections, to our knowledge. Among the pre-operative biological constants, we found that only the decrease in hematocrit was statistically significantly associated with death.

Coagulase-negative Staphylococcus was the most frequently isolated germ from patients in the 7th decade of life (104 patients, $\mathrm{p}=0.022$ ). This is in line with what we already know about this pathogenic opportunistic germwhich crosses the skin barrier with the occasion of venous punctures and of implants of all kinds, especially in elderly, immunosuppressed patients and after many days of hospitalization.

Tropism of bacteria for certain organs or systems found in our study correlates with literature data for both biliary tract infections (25) and also for acute appendicitis $(26,27)$ and acute peritonitis $(28)$, most of which are community-acquired infections, with the exception of biliary tract infections with Acinetobacter baumannii who were all nosocomial infections, associated with pneumonia. The most commonly used criteria for choosing empiric antibiotic therapy initiated at patient hospitalization was the low cost of large-scale antimicrobial medication: Ceftazidime, Ampicillin, Metronidazole and Gentamicin.This choice was not the best in terms of local microbial resistance, specific to our hospital, that has not yet been tested, and in terms of antibiotic guidelines that have not been fully respected due to prescription restrictions independent of the surgeon. Upon obtaining the antibiogram result, the treatment was administered in accordance with this, but we can't be sure that the specific antibiotic therapy didnot select other pathogens, as we can't carry out studies of virulence or microbial genetic in the laboratory. The combination of Ceftazidime with Metronidazole - most used in the empirical treatment of digestive tract infections, appears to produce resistance and selection of other pathogenic germs and is not found in the results of antibiogram obtained in patients who have evolved unfavorably.

Deaths occurred statistically significantly more frequently in Enterococcus, E. coli, Acinetobacter and Candida infections. In all these cases, patients were treated with Ertapenem (Invanz), reflecting the severity of the cases and the outcome of the antibiogram. We don't know whether the source of the infection was controlled in these patients or whether organ dysfunctions were associated. Enterococcus spp. infection was found to be an independent risk factor for postoperative mortality in intra-abdominal infections by Wacha et al. (29).In addition to insufficient surgical control of the focal origin of the sepsis, comorbidities, and age of the patient, the progression to death seems to be favored by the particular virulence demonstrated by Enterococcus faecalis and faecium by the production of cytolysin and the aggregation substance $(30,31)$ but also because of the variability of capsular proteins that provide one of the most powerful antibiotic resistance (32).In our study, the large number of patients who died of Enterococcus infection is due to all the factors discussed above, that will need to be reviewed, especially source control, treatment of associated diseases and targeted antibiotics by more frequent testing of bacterial resistance.

E. coli is a very heterogeneous species with multiple alleles that provide a special plasticity (33) and resistance to $\beta$-lactam and gene encoded carbapenem, which is more rapidly gained and more complex as the patient has been treated with antibiotics for longer and has more days of hospitalization (34). In our study, of the 22 patients who died of E. coli infection, only 3 acquired the bacterium in the hospital, the nosocomial infection mortality was not statistically significantly higher in these cases $(\mathrm{p}=0.07)$.The high rate of death associated with $\mathrm{E}$. coli suggests that the empirical treatment with Gentamicin and Metronidazole used in GSD of BMECH is not effective and should be replaced considering the microbial resistance.

In regard to fungal infections, there were no reported deaths in Candida patients from community acquired infections, all 6 patients that died with this infection had many days of hospitalization with long-term antibiotic treatment to which the antifungal medication was administered only at the end and only for a few days, this being the reason why Fluconazole does not appear statistically significant in the treatment of these patients. In the case of community-acquired Candida infections, all 7 patients recovered, although antifungal treatment was given only for 2 of them, natural immunity being sufficient in these cases in addition to controlling the source of the infection $(35,36)$.The high mortality of patients infected with Acinetobacter (10 out of 23, 43.47\%) was mainly due to pneumonia with Acinetobacter baumannii (7 patients) and is consistent with the specialty literature (37). The fact that out of the 23 cases, 6 were diagnosticated upon admission (patients transferred from other hospitals) and 17 were hospital-acquired infections, suggests that we need to reconsider patient isolation because the antibiotic treatment was correctly administered. 


\section{Conclusions}

The most common surgical infections are those community acquired. The most common isolated germ was E. coli which determined the most frequent deaths between monomicrobial infections. Along with this, Enterococcus, Candida and Acinetobacter infections had a higher rate of death and generated the highest hospitalization costs. Strict isolation of patients with Acinetobacter baumannii is required as the most effective measure for reducing mortality through this infection. The association of anemia at the admission of patients with infections increases the risk of death and is associated with the highest costs of hospitalization.

The authors have no competing interest to declare.

\section{References}

Dellinger EP, Surgical Infections: Introduction and Overview in Netter's Infectious Diseases, Elsevier 2012, pp 238-9

Bowler PG, Duerden BI, Armstrong DG, Wound microbiology and associated approaches to wound management, Clin Microbiol Rev. 2001 Apr;14(2):244-69

Lebeaux D, Ghigo JM, Management of biofilm-associated infections: what can we expect from recent research on biofilm lifestyles, Med Sci (Paris). 2012 Aug-Sep;28(8-9):727-39

Lax S, Sangwan N, Smith D, Larsen P, Handley KM, Richardson M, Guyton K, Krezalek M, Shogan BD, Defazio J, Flemming I, Shakhsheer B, Weber S, Landon E, Garcia-Houchins S, Siegel J, Alverdy J, Knight R, Stephens B, Gilbert JA, Bacterial colonization and succession in a newly opened hospital, Sci Transl Med, 2017 May 24;9(391)

Culver DH, Horan TC, Gaynes RP, et al, Surgical wound infection rates by wound class, operative procedure, and patient risk index, Am J Med, 1991;91(suppl 3B):S152-S157

Shah PM, Edwards BL, Dietch ZC, Guidry CA, Davies SW, Hennessy SA, Duane TM, O'Neill PJ, Coimbra R, Cook CH, Askari R, Popovsky K, Sawyer RG, Do PolymicrobialIntra-Abdominal Infections Have WorseOutcomes than MonomicrobialIntra-Abdominal Infections, Surg Infect (Larchmt). 2016 Feb;17(1):27-31

Lipsky BA1, Tabak YP, Johannes RS, Vo L, Hyde L, Weigelt JA, Skin and soft tissue infections in hospitalised patients with diabetes: culture isolates and risk factors associated with mortality, length of stay and cost, Diabetologia. 2010 May;53(5):914-23

Banning M, Bacteria and the gastrointestinal tract: beneficial and harmful effects, Br J Nurs. 2006 Feb 922;15(3):144-9

Ceci M, Delpech G, Sparo M, Mezzina V, Sánchez Bruni S, Baldaccini B, Clinical and microbiological features of bacteremia caused by Enterococcus faecalis, J Infect Dev Ctries. 2015 Nov 30;9(11):1195-203

Becker K, Heilmann C, Peters G, Coagulase-negative staphylococci, Clin Microbiol Rev. 2014 Oct;27(4):870-926

Lim KT, Hanifah YA, Yusof MY, Thong K, Characterisation of the Virulence Factors and Genetic Types of Methicillin Susceptible Staphylococcus aureus from Patients and Healthy Individuals, Indian J Microbiol. 2012 Dec;52(4):593-600

Abdelsattar ZM, Krapohl G, Alrahmani L, Banerjee M, Krell RW, Wong SL, et al. Postoperative Burden of Hospital-Acquired Clostridium difficile Infection. Infect Control Hosp Epidemiol. 2015;36(1):40-6

Nichols RL, Smith J, Clinical aspects of anaerobic infections in the surgical patient, Am J Med Technol. 1975 Nov;41(11):431-6

Bohnen JM, Solomkin JS, Dellinger EP, Bjornson HS, Page CP, Guidelines for clinical care: anti-infective agents for intra-abdominal infection. A Surgical Infection Society policy statement, Arch Surg , 1992, vol. 127 (pg. 83-9)

Rubio-Perez I, Martin-Perez E, Domingo-García D, Garcia-Olmo D, Specific Clinical Profile and Risk Factors for Mortality in General Surgery Patients with Infections by Multi-Drug-Resistant Gram-Negative Bacteria, Surg Infect (Larchmt). 2017 Jul;18(5):625-633

Peralta G, Lamelo M, Alvarez-Garcia P, et al, Impact of empirical treatment in extended-spectrum betalactamaseproducing Escherichia coli and Klebsiella spp. bacteremia. A multicentric cohort study, BMC Infect Dis 2012;12:245 
Gudiol C, Calatayud L, Garcia-Vidal C, et al, Bacteraemia due to extended-spectrum beta-lactamase-producing Escherichia coli (ESBL-EC) in cancer patients: Clinical features, risk factors, molecular epidemiology and outcome, J Antimicrob Chemother 2010;65:333-341

Leșe M, Ţigan Ş, Systemic Inflammatory Response Syndrome and Organ Insufficiencies in Precocious Evolution of Acute Pancreatitis, Applied Medical Informatics, Vol 19, No 3, 4 (2006)

Beutler E, Hemolytic anemia due to infections with microorganism, in New York : McGraw-Hill Education, 2018

Koç F, Bekar L, Kadı H, Ceyhan K, Hemolysis and infective endocarditis in a mitral prosthetic valve, Turk Kardiyol Dern Ars. 2010 Sep;38(6):429-31

Spomer A1, Ho G Jr, Bacterial endocarditis and septic arthritis presenting as polymyalgia rheumatica, R I Med. 1994 Jan;77(1):5-6

Jahan A, Bhutia E, Yadav TP, Klebsiella infection-associated autoimmune haemolytic anaemia, JIACM 2013; 14(2): 190-1

Moon Y, Jang WR, Yi HG, Park IS, Nahm CH, Choi JW, Kim JJ, Han SB, Klebsiella pneumoniae associated extreme plasmacytosis, Infect Chemother. 2013 Dec;45(4):435-40

Wanachiwanawin W, Infections in E-beta thalassemia, J Pediatr Hematol Oncol. 2000 Nov-Dec;22(6):581-7

Sung YK1, Lee JK, Lee KH, Lee KT, Kang CI, The clinical epidemiology and outcomes of bacteremic biliary tract infections caused by antimicrobial-resistant pathogens, Am J Gastroenterol. 2012 Mar;107(3):473-83

Parthiban N, Harish M, A study on microbiology culture of acute appendicectomy specimen and its correlation with wound infection, Int Surg J. 2017 Jul;4(7):2212-2215

Larbcharoensub N1, Boonsakan P, Kanoksil W, Wattanatranon D, Phongkitkarun S, Molagool S, Watcharananan SP, Fungal appendicitis: a case series and review of the literature, Southeast Asian J Trop Med Public Health. 2013 Jul 4;44(4):681-9

Mujais S, Microbiology and outcomes of peritonitis in North America, Kidney Int Suppl. 2006 Nov;(103):S55-62

Wacha H, Hau T, Dittmer R, Ohmann C, Risk factors associated with intraabdominal infections: a prospective multicenter study. Peritonitis Study Group, Langenbecks Arch Surg. 1999 Feb;384(1):24-32

Dupont H., Montravers P., Mohler J., Carbon C, Disparate findings on the role of virulence factors of Enterococcus faecalis in mouse and rat models of peritonitis. Infection and Immunity. 1998;66(6):25702575

Ike Y., Hashimoto H., Clewell D. B, Hemolysin of Streptococcus faecalis subspecies zymogenes contributes to virulence in mice. Infection and Immunity. 1984;45(2):528-530

Shankar V., Baghdayan A. S., Huycke M. M., Lindahl G., Gilmore M. S, Infection-derived Enterococcus faecalis strains are enriched in esp, a gene encoding a novel surface protein. Infection and Immunity. 1999;67(1):193-200

Donnenberg MS, Whittam TS, Pathogenesis and evolution of virulence inenteropathogenic and enterohemorrhagic Escherichia coli, J Clin Invest. 2001;107(5):539-548

Peirano G, van der Bij AK, Gregson DB, Pitout JD, Molecular epidemiology over an 11-year period (2000 to 2010) of extended-spectrum $\beta$-lactamase-producing Escherichia coli causing bacteremia in a centralized Canadian region, J Clin Microbiol. 2012 Feb; 50(2):294-9

Calandra T, Bille J, Schneider R, Mosimann F, Francioli P, Clinical significance of Candida isolated from peritoneum in surgical patients, Lancet. 1989 Dec 16;2(8677):1437-40

Rutledge R, Mandel SR, Wild RE, Candida species. Insignificant contaminant or pathogenic species, Am Surg. 1986 Jun;52(6):299-302

Lee YT, Kuo SC, Yang SP, Lin YT, Tseng FC, Chen TL, Fung CP, Impact of appropriate antimicrobial therapy on mortality associated with Acinetobacter baumannii bacteremia: relation to severity of infection, Clin Infect Dis. 2012 Jul; 55(2):209-15 